\title{
DME 化学再生ガスタービンの実証試験*
}

中坦隆雄*1, 大橋幸夫*2, 高橋 武雄*3

山中 矢 ${ }^{* 4}$, 佐 藤純一*5

笹部 和 宏*5, 渡 邊 恒 典*5

\section{Demonstration Test of}

\section{DME-Fueled Chemically Recuperated Gas Turbine}

Takao NAKAGAKI*6, Yukio OHASHI, Takeo TAKAHASHI,

Susumu YAMANAKA, Junichi SATO,

Kazuhiro SASABE and Tsunenori WATANABE

${ }^{* 6}$ Department of Modern Mechanical Engineering, Waseda University, 3-4-1 Okubo, Shinjuku-ku, Tokyo, 169-8555 Japan

Chemically Recuperated Gas Turbine (CRGT) is an advanced GT cycle that can increase power generation efficiency by recovering the exhaust heat with endothermic reaction of steam reforming. The CRGT fueled by Dimethyl Ether (DME) was demonstrated using $30 \mathrm{~kW}$ Micro GT (MGT) and accomplished both $10 \%$ reduction of fuel consumption compared with steam injected GT cycle and NO $x$ emission level of less than $10 \mathrm{ppm}$. Alternative fuel nozzle had concentric double pipe, one of which was designed to burn DME directly with diffusive combustion, and the other was premixed combustion of low-BTU reformed gas. The reformer, which was designed to fit into the MGT consisted of 96 SS 316-tubes filled with Pt catalyst and alumina balls, top and bottom headers and rectangular duct, recovered $15.3 \mathrm{~kW}$ heat from exhaust gas and increase heating value by $7.9 \%$.

Key Words: Steam Reforming, Steam Injection, Cogeneration System, Micro Gas Turbine

\section{1. 実証試験システムの概要}

水蒸気と混合した燃料の改質反心によって排熱を回 収する化学再生サイクルは，ガスタービンコージェネ レーションシステムに発電効率后上と低 $\mathrm{NO}_{\mathrm{x}}$ エミッシ ヨンをもたらす.開発目標は数 MWクラスで $40 \%$ 超の 発電効率であるが，今回，経済産業省の補助事業で, ジメチルエーテル (DME) とその改質ガスを燃料とす る $30 \mathrm{~kW}$ マイクロガスタービン（MGT）在用いた発電 実証試験に成功したので報告する.

実証試験システムを図 1 に示す. MGT 本体の起動お よび出力開始に伴う受送電の系統連系を模擬するため に, 試験電源をディーゼルエンジン発電機, トランス, 水抵抗負荷などで構成した. MGT はシンプルサイクル で連転し，水ポンプ，水予熱器，蒸発器および蒸気過 熱器などで構成される蒸気系, DME ポンプ, DME 加 熱器, 改質器およざ然料ノズルなどで構成される燃料 系を追加した. MGT ファームウエアの持つ強力な保護 回路や制御シーケンスもそのまま活用しつつも, MGT

* 原稿受付 2008 年 9 月 19 日.

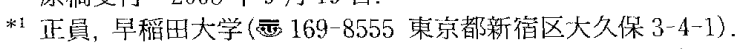

*2 IF.員，(株)東芝電カシステム社(五 230-0045 横浜市鶴見区 末広町 2-4)

*3 (株) 東芝電力システム社 (画 105-8001 東京都港区芝浦 1-11).

*4 (株) 東芝電力システム社.

*5 関西電力 (株) 電力技術研究所 ( 661 -0974 尼崎市若王寺 3$11-20)$

E-mail: takaonakagaki@waseda.jp
やポンプ類の起動停止, バルブ類の制御と緊急時の保 安システムを司る制御盤も新設した。

化学再生の運転確立には, DME 生焚きから改質ガス 燃焼への切り替え操作が必要であるため, 燃焼器周り の改造も避けられない，図 1 に示した代替燃料ノズル は，パイロットノズルとなる内管に DME 拡散燃焼, メインノズルとなる外管に改質ガス予混合燃焼の機能 を持たせた二重管構造である. $400^{\circ} \mathrm{C}$ 以上になる改質ガ スは, $40 \mathrm{vol} \%$ 前後の $\mathrm{H}_{2}$ と約 $14 \%$ O CO 石可燃成分と L，不活性な $\mathrm{CO}_{2}$ と $\mathrm{H}_{2} \mathrm{O}$ も多く含んでいる. 改質力゙ス のウォッべ指数と体積あたりのLHVをDMEと比較す ると，それぞれ約 $1 / 4$ と 1/7 程度となるため, 改質ガス の噴出孔は大幅に拡大するよう設計した。

化学再生サイクルのキーコンポーネントである改質 器は，SUS316 製の千鳥格子管群で，Pt-0.5wt\%触媒を 充填した内部に改質ガスを，外部に排気をそれぞれ流 す一種の熱交換器である．改質器の性能は，排熱回収 量や燃料発熱量の増分として LHV 増加率などの指標 を用いて評価する．改質反店では，DMEの加水分解に よるメタノール生成が律速段階であり，発熱反応であ るCOシフトおよびメタン生成反忘の抑制のため，蒸 気と DME のモル比を最小量論比である 3 に，反応温

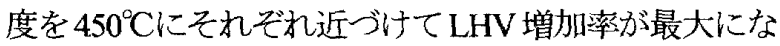




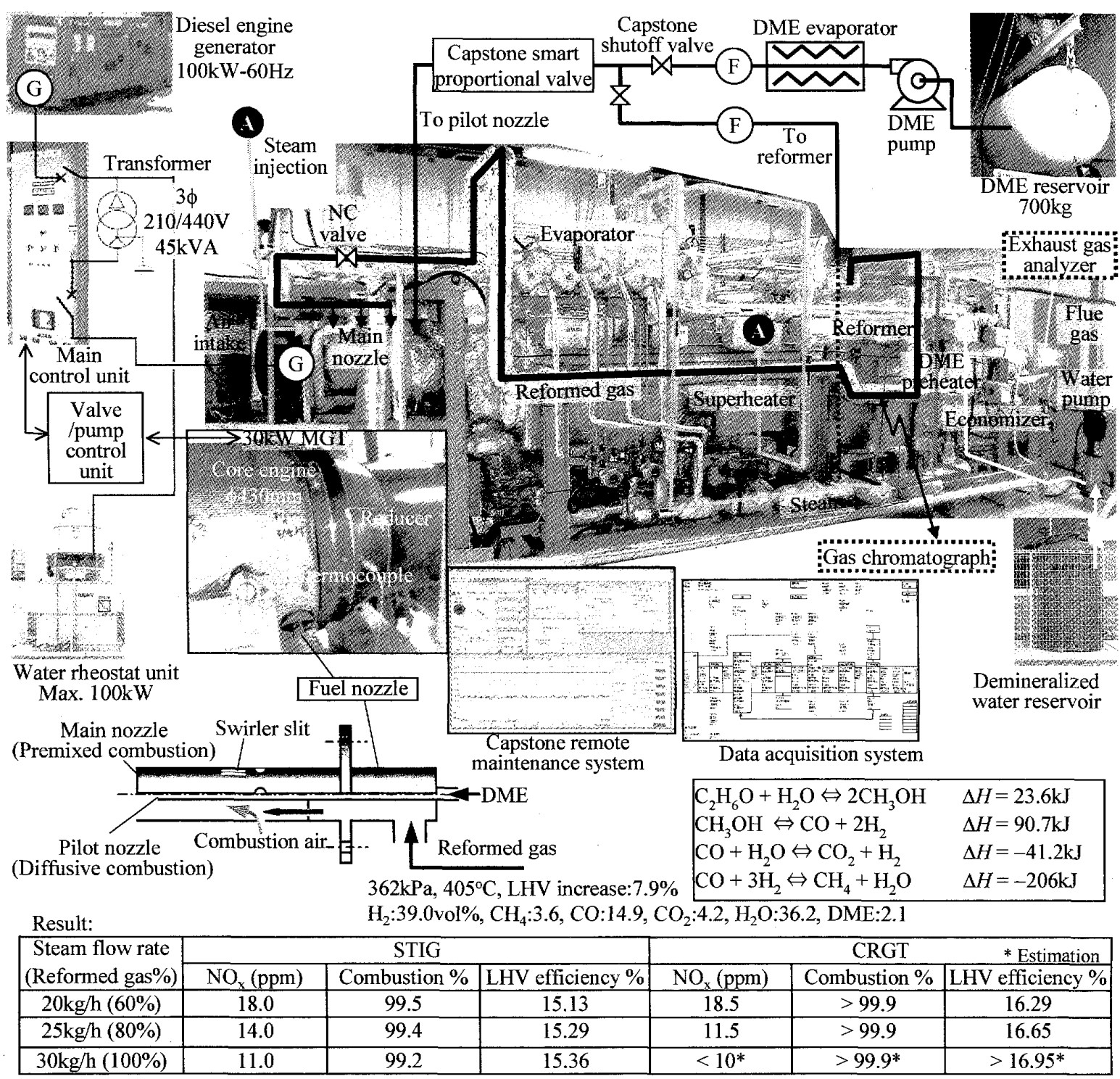

Fig. $130 \mathrm{~kW}$ CRGT demonstration test system

るように, 実験と数値解析により反応器を設計した.

\section{2. 試験手順と結果}

まず，自動負荷追従モードで運転されているディー ゼルエンジン発電機を電源として MGT を起動し, 定 格の $30 \mathrm{~kW}$ まで，パイロットノズルによる DME 拡散 燃焼のみで出力を漸次上昇させ，シンプルサイクルで 蒸気系を暖気運転した．次に，改質器をパージさせた 過熱蒸気をメインノズルからパイロット拡散燃焼の周 囲に噴射し，噴射蒸気量をパラメータにして蒸気噴射 サイクル運転モードのデータを取得した。最後に， DME を少しずつ改質器へ導入して改質ガスをメイン ノズルで予混合燃焼させ，ファームウエアが異常と判 断して停止するまで改質燃料割合を増加させた．改質 燃料流量比 $90 \%$ で海時間の運転は可能であったもの の出力が極めて不安定であり, 最終的に S/DME=3.5 付
近, 60〜80\%のデータを基に 100\%改質運軽は外挿によ って推定した. 図 1 に蒸気噴射サイクルと化学再生サ イクルの発電効率, 燃焼効率および $\mathrm{NO}_{\mathrm{x}}$ 濃度の結果を, 蒸気流量をパラメータとして示す. 100\%改質ガス定格 運転における発電効率の推定值は，シンプルサイクル の実測值 $14.7 \%$ に対しては相対的に $13.3 \%$, 蒸気噴射 サイクルに対しても同 $10.4 \%$ 向上が見られ，化学再 生サイクルの優位性を実証した。排熱回収系として評 価すれば, DME加熱器で $4.4 \mathrm{~kW}$, 改質器で $15.3 \mathrm{~kW}$ を 回収し, 改質ガスの LHV は DMEに対して 7.9\%の増 加となった. また, 燃焼効率 $99 \%$ 以上で, $\mathrm{NO}_{\mathrm{x}}$ も $10 \mathrm{ppm}$ を下回ることを確認した. 化学再生サイクルは, 発電 規模によらず一定の発電効率向上が望めることから， 既存のコージェネレーションシステムに導入すれば, $\mathrm{NO}_{\mathrm{x}}$ 排出基準をクリアしつつも，最大で $10 \%$ の燃料費 あるいは $\mathrm{CO}_{2}$ 排出の削減が可能であることを実証した。 